\title{
The Decade 1989-1998 in Spanish Psychology: An Analysis of Research in Psychobiology
}

\author{
Pilar Herreros de Tejada and Carmen Muñoz Tedó \\ Complutense University of Madrid
}

In this paper, we present an analysis of the research published during the 1989-1998 decade by tenured Spanish faculty members from the area of psychobiology. Database search and direct correspondence with the 110 faculty members rendered a list of 904 psychobiological papers. Classification and analysis of these papers led to the definition of at least 70 different research trends. Topics are grouped into several specific research areas: Learning and Memory; Development and Neural Plasticity; Emotion and Stress; Ethology; Neuropsychology; Sensory Processing; and Psychopharmacology. The international dissemination of this research, published in journals of high impact index, and the increasing number of papers are two noteworthy features.

\begin{abstract}
En este estudio se analiza la investigación publicada en la década 1989-1998 por los profesores numerarios españoles del área de la psicobiología. La búsqueda en las bases de datos y correspondencia directa con los 110 profesores dio como resultado una lista de 904 artículos publicados de psicobiologia. La clasificación y análisis de estos artículos llevó a la definición de al menos 70 líneas de investigación diferentes. Se agrupan los temas en varias áreas de investigación: aprendizaje y memoria; desarrollo y plasticidad neuronal; emoción y estrés; etologia; neuropsicología; procesamiento sensorial; y psicofarmacologia. La proyección internacional de esta investigación, publicada en revistas de alto indice de impacto, y el numero creciente de artículos son dos caracteristicas importantes.
\end{abstract}

Correspondence concerning this article should be addressed to Dr. Pilar Herreros de Tejada, Departamento de Psicobiología, Facultad de Psicología. Campus de Somosaguas. 28223-Madrid (Spain). E-mail: pspsc03@sis.ucm.es 
In this paper, we attempt to offer an overview of the research carried out in the area of psychobiology by tenured faculty members (professors) from the Spanish universities in which the Psychology licentiate is taught. The method employed is described in detail elsewhere in this special issue (see Fernández). Therefore, we shall only comment upon the specific aspects involved in this area of knowledge.

On April 4, 1999, the "Listado del Consejo de Universidades" (University Council List) of the tenured Psychobiology professors reached the number of 110 (distributed in 19 universities, see Figure 1A). This is considerably lower than the number of professors from other areas included in this monographic number, because except for Methodology, almost all of these areas have twice or three times this number. On the basis of this list, we carried out a bibliographic search in the international databases MEDLINE, PsycLIT, and ERIC, as well as in the national database PSICODOC98, in order to obtain the list of publications by each professor.

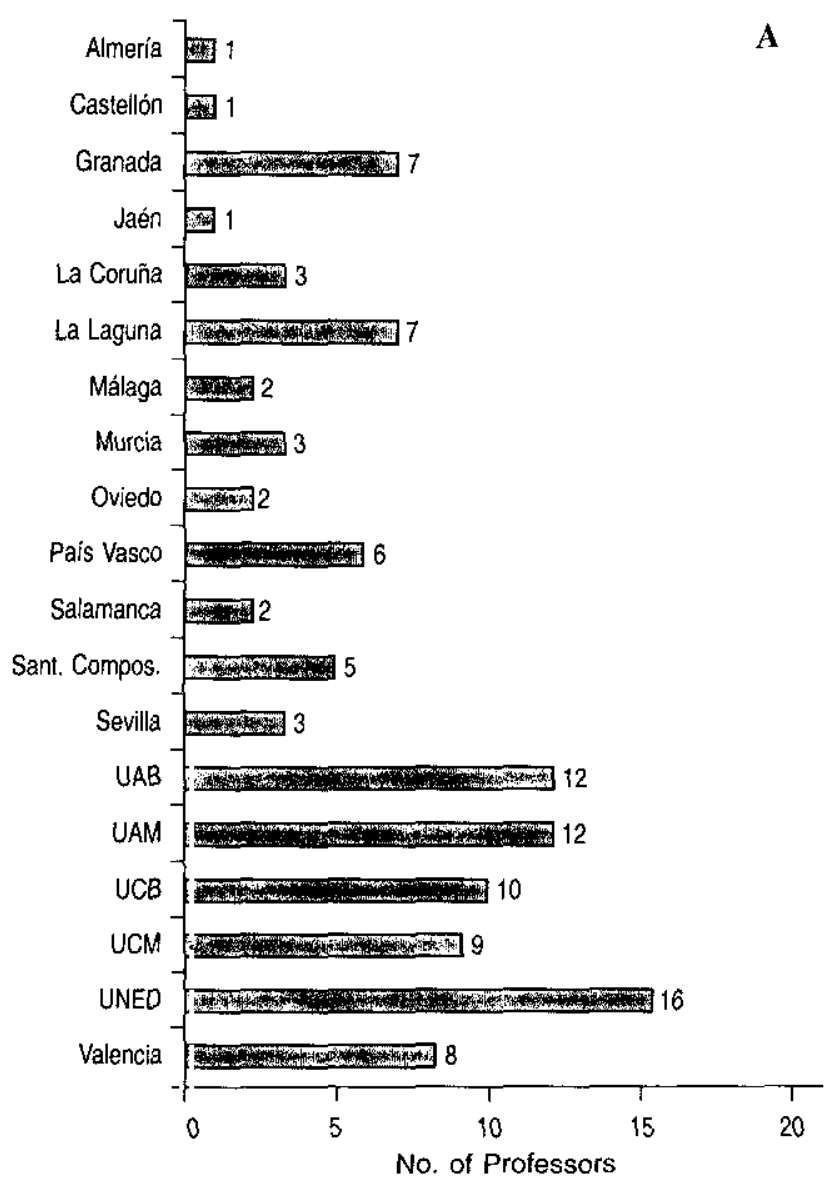

\section{Stage One - Making a List of Publications}

As described by Fernández, in this monographic issue, we wished to make a list of available publications for interested readers, taking into account that the goal is to describe the research trends of each area. Therefore, popular works, theoretical reviews of topics that cannot be considered the research trend proper, and publications for teaching, were discarded. The problem of locating Spanish surnames in national and international databases is well known. In addition, the databases that include most of the works by psychologists are social sciences databases, from which the works by psychobiologists are often excluded. For example, the database MEDLINE included most of the works by professors listed as Psychobiology professors, whereas ERIC did not include practically any. Some areas, such as ethology, were not well represented in any of these databases. In order to counteract these problems, we contacted all the terured

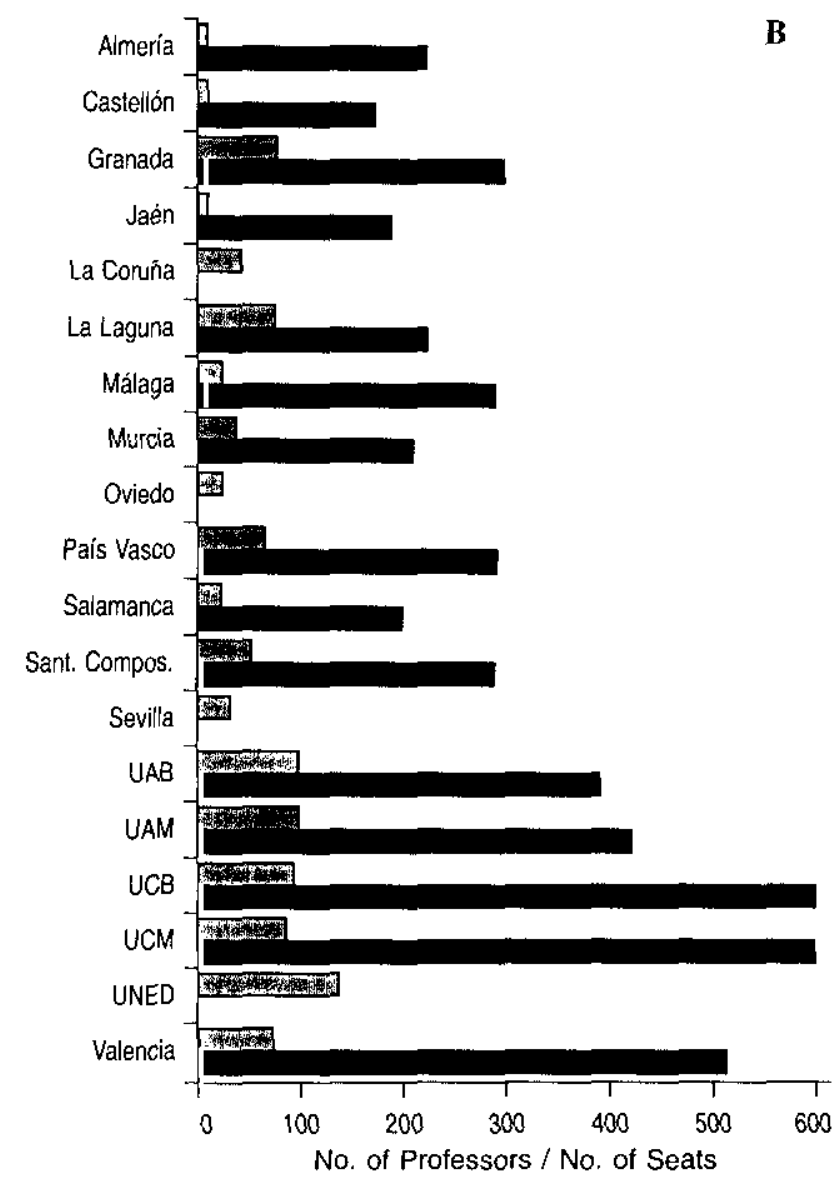

Figure 1. Number of Psychobiology professors in Spanish universities in April 1999.

A.- Distribution of the number of tenured professors by universities

B.- In each university, the number of professors (from Figure IA) is compared with the number of seats offered to students, which corresponds to the values of the axis of abscissas and is represented by black bars. For the Complutense University of Madrid and the Autonomous University of Barcelona, the values are over 600 seats. (The data about seats in the universities are taken from the article by $J$, Fernández.) 
university professors, and sent them our list of their publications. This was well received. Guided by their responses, we were able to complete a total list of over 900 publications (74\% in English). This number refers exclusively to works that meet publication requirements and it is an indication of the intense and fruitful research activity of Psychobiology professors. Many of these articles are signed by more than one teacher from the Psychobiology list, so that if we add up the publications included for each professor individually, the number is over 1,400 articles.

We identified 70 research trends. This number is approximate, as in some cases, it would have been possible to divide a research trend into several trends, because, over the decade, some research groups have diversified their publications. Nevertheless, if the object of study was internally coherent, we decided not to divide the research trends, unless the group components suggested the opposite.

Therefore, in this first stage, we highlight the following features of the area of Psychobiology: (a) a large number of publications by the majority of the professors; (b) a marked international dissemination of the research trends, because most of the works are published in English and, in general, in journals of high impact index; (c) a high concordance between the areas in which professors teach and those in which they carry out their research.

\section{Stage Two - Elaborating the Research Trends and Grouping them into Specific Areas}

The second stage of this study consisted of elaborating the research trends proper. For this purpose, we again contacted the professors who worked in a research trend to invite them, if they so wished, to cooperate in the description of the most representative aspects of their work. In research trends with participation by several professors, we contacted at least two of them. In at least $80 \%$ of the research trends, some of the participants collaborated in their descriptions.

A series of categories (see Table 1) corresponding to those used in most of the journals of this area was used as the organization criteria for the various research trends. These specific research areas and the number of research trends identified in each area are shown in Figure 2. The number of professors who work in each specific area is also

Table 1

Specific Research Areas used in this Work

Learning and Memory

Development and Plasticity of the Nervous System

Emotion and Stress

Ethology

Neuropsychology

Sensory Processing

Psychopharmacology shown, although some professors may be counted twice, because the same person may be working in more than one area. Within each of these categories, the information is organized as follows: (1) an introductory paragraph which states the number of research trends included in the section, and some representative characteristics of the specific area; (2) a paragraph describing each research trend; (3) a paragraph which mentions research trends described in another specific area, but which could have been included in the current area.

A twofold criterion was employed to select the references for each research trend. On the one hand, we attempted to present the works of the greatest impact and, on the other, in order to aid readers, those works that present a more relevant notion of the research trend. Given the large quantity of publications by professors in this area, a maximum number of two works per research trend were quoted. There are only three exceptions where more works were quoted and this is due to the aforementioned cases. That is, those research trends that could have been subdivided into more trends, but were not. On the other hand, readers may be surprised to find references published after 1998 . When establishing the research trends, only works published between 1989 and 1998 were considered, but once a trend was established, subsequent works were considered as possible references providing they met the goal of presenting and disseminating the work of the trend.

The specific research areas are described below.

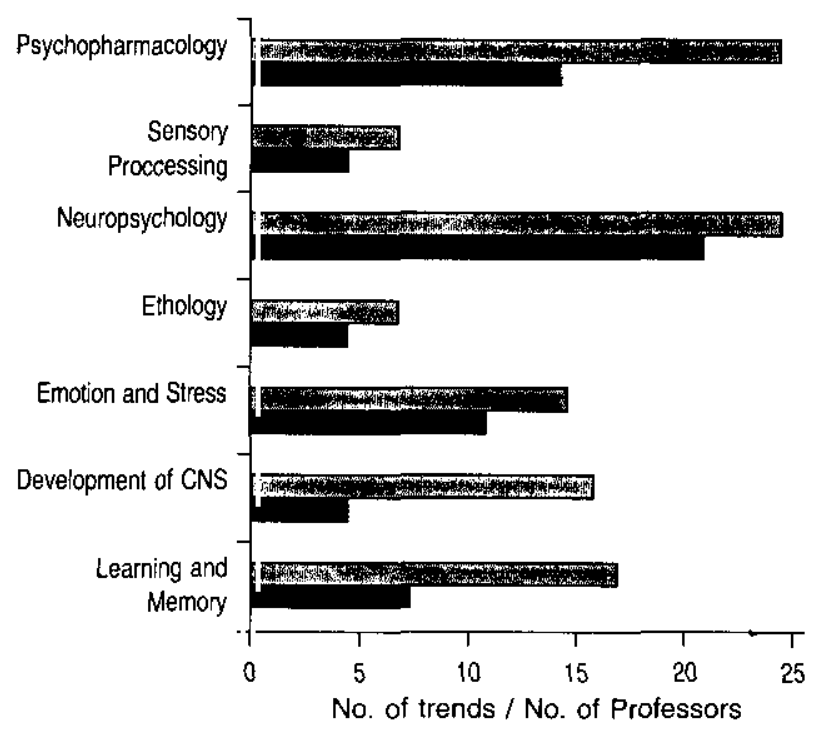

Figure 2. Number of trends and professors grouped by specific research (1989-1998).

Black Bars: Number of research trends. Gray Bars: Number of professors in each specific research area (The professors appear in more than one specific area if they participate in the corresponding research trends.) 


\section{Specific Research Areas}

\section{Learning and Memory}

In this area, we identified a total of 8 research trends, 2 of which - the first and the last-could have been subdivided. In this specific area, research is being carried out with animals. Most of the trends use rats as experimental subjects, although some use birds and fish. Various types of learning were employed, such as avoidance, aversive and interoceptive learning, spatial orientation or intracranial selfstimulation. Within biology of learning and memory processes, the trends range from molecular studies to the generation of models of memory retrieval.

The first research trend corresponds to a group of studies of the visceral-brain system via various homeostatic behavior processes such as nutrition (Ramos, Castillo, \& Puerto, 1989) and hydro-mineral regulation (Morales, Cubero, \& Puerto, 1989), or acquisition processes such as interoceptive leaming (Arnedo, Gallo, Agüero, Molina, \& Puerto, 1993; Mediavilla, Molina, \& Puerto, 1998). Within this trend, two learning modalities have been anatomically and behaviorally dissociated: On the one hand, concurrent aversive learning (instrumental), which involves the vagal axis, the medial parabrachial nucleus, and cerebellum circuits (Agüero, Gallo, Arnedo, Molina, \& Puerto, 1996) and, on the other, sequential aversive learning (which is relational), mediated by the area postrema and the lateral parabrachial nucleus (Agüero, Arnedo, Gallo, \& Puerto, 1993). The final goals of this group of researchers are to characterize functionally the behavioral dichotomy between these two types of aversive learning, and to establish the anatomical circuits involved both in learning and in memory modalities.

The interest in locating the basic associative brain site for taste-aversion learning has led to the application of reversible brain inactivation by intracerebral injections of tetrodotoxin (Gallo, Márquez, Ballesteros, \& Maldonado, 1999). The data showing that the postrial functional inactivation of the parabrachial area disrupts motion-sicknessinduced taste aversion reveals an associative role for the area, independent of the sensory functions. A related approach, using taste-aversion learning as the learning procedure, concerns the study of the neural basis of complex learning phenomena that may require interactions among independent brain systems. It has been shown that conditioned blocking, but not Jatent inhibition of tasteaversion learning, requires an intact hippocampus, and that the blocking effect may be reestablished in hippocampallesioned rats by transplants of fetal brain tissue (Gallo, Valouskova, \& Cándido, 1997).

A third research trend has studied, in day-old chicks, the role of various cerebral areas in passive avoidance learning, for the first time implicating the hippocampus among the regions that mediate this learning. It has also been established that functional lateralization, manifested in the medial and intermediate hyperstriate, is related to asymmetry in the visual projection pathways. The role of nitric oxide and the growth factor of fibroblasts in exploratory locomotor behavior and novel situations, which might interfere with learning processes (Sandi, Patterson, \& Rose, 1993), was also studied, in rats.

Neural plasticity in learning is also addressed by comparative study of the neural basis of learning and memory, in vertebrates, using behavioral, lesion, electrophysiological, and neuroanatomical techniques (Salas, Rodríguez, Vargas, Durán, \& Torres, 1996). These authors also study the tectoreticular and telencephalic systems that participate in the generation and control of spatial orientation movements in vertebrates (Salas, Herrero, Rodríguez, \& Torres, 1997).

Another research trend on spatial orientation behavior examines the structures involved, such as the hippocampal formation, anterior thalamus, and mammillary bodies, in rats, analyzing the number of neurons, glial cells (especially the astroglial cells), oxidative metabolism and protein synthesis. The authors have described the consolidation of spatial orientation behavior earlier in male rats than in females, and the possibility of modifying it by hormonal manipulation (Cimadevilla et al., 1999). This behavior has been associated with the maturity and neural stabilization of several limbic structures. Metabolism within this Papez circuit throughout postnatat development and aging has also been differentiated (González-González, Díaz, Vallejo, \& Arias, 1996).

The last three research trends presented in this section are focused on the study of memoty consolidation and retrieval processes. Researchers are carrying out experimental designs aimed fundamentally at the role of the amygdala and the hippocampus in the memory of emotional processes and in the process of memory consolidation of discrete events, those that only occur once in time and space (PeinadoManzado, 1994; Peinado-Manzado \& Pozo-García, 1996).

The study of the role of stress and glucocorticoids in the cerebral mechanisms involved in learning and memory processes has revealed that the release of glucocorticoids during learning facilitates the processes of long-term information transfer. The facilitating effects of glucocorticoids in memory processes have also been studied, and the involvement of the neural cellular adhesion molecules (Sandi, Loscertales, \& Guaza, 1997; Sandi \& Rose, 1994) was observed.

A group of researchers has established experimental models of amnesia in rats and developed models of memory retrieval and facilitation in complex learning (GuillazoBlanch, Vale-Martínez, Martí-Nicolovius, Coll-Andreu, \& Morgado-Bernal, 1999; Torras-García, Portell-Cortés, CostaMiserachs, \& Morgado-Bernal, 1997). The treatments developed are capable of accelerating and potentiating the process of memory consolidation, causing the subjects that learn less to reach the same level as those that leam more. Memory facilitation by means of intracranial electrical self- 
stimulation in old rats was also observed (Aldavert-Vera et al., 1997). The results show that lesions or electrical stimulation of nuclei related to cortical and cognitive activation of the brain (neural arousal systems), such as the parafascicular, the thalamic reticular, the tuberomammillary, the peduncle-pontine or the basal magnocellular nuclei, can facilitate acquisition or long-term retention of learning. This suggests that the subcortical and brain stem structures involved in the different arousal systems might be critical for the formation and potentiation of memory (Tenas-Huerga, Coli-Andreu, Guillazo-Blanch, Martí-Nicolovius, \& Morgado-Bernal, 1998; Vale-Martínez, Guillazo-Blanch, Aldavert-Vera, Segura-Torres, \& Marti-Nicolovius, 1999). On the basis of the hypothesis that each neural arousal system contributes some specific quality (cognitive, physiological, or molecular) to cortical information processing, the authors of this research trend attempt to discern the specific role of the different neural arousal systems in memory consolidation.

In the above paragraphs, we have described eight research trends in this specific area of Learning and Memory. Although some more trends could also be included here, they were included in another section. Thus, in the Psychopharmacology section, we include a trend that studies the effects of psychoactive drugs on avoidance learning in rats (Morales, Torres, Megías, Cándido, \& Maldonado, 1992). In the section on Emotion, we also present a trend in which learning measurements are conducted on hyperand hypo-emotional rats (Fernández-Teruel, Escorihuela, Castellano, González, \& Tobeña, 1997).

\section{Development and Plasticity of the Nervous System}

In this area, five research trends study the development of the nervous system and of behavior in rats and hamsters. The first three trends, very interrelated, study aspects of sexual differentiation of the vomeronasal system (VNS) in rats, by the action of the gonadal steroids and the GABA neurotransmitter. The studies employed a morphological and endocrinological, as well as a behavioral, outlook (sexually differentiated behaviors such as sexual and parenting behavior). The other two trends study, among other aspects, the influence of gestating mothers' malnutrition on the development of the nervous system.

The works of the first research trend are focused on the effects of dihydrotestosterone on the process of sexual differentiation of the nervous system (Collado et al., 1992; Valencia et al., 1992).

The second research trend is centered on maternal behavior, examining the hypothesis of vomeronasal inhibition on the neural control of this behavior (Cerro, 1998). The effects of prenatal environmental stress on the differentiation of the central nervous system (CNS) (in the VNS) and on the expression of matemal behavior are also studied (Cerro et al., 1995).
Lastly, the role of the VNS in sexual dimorphism in rats was studied and the most significant conclusions were: (a) Sexual differentiation in the nervous system does not occur in isolated neural structures; rather, it affects complex neural circuits (such as the SVN); (b) masculinization of females or feminization of males at the neural level is related causaliy to the inversion of maternal behavior (maternal care of offspring is inhibited in the females and facilitated in the males); and (c) in addition to steroid hormones, other factors also intervene in the sexual differentiation process of the nervous system and of behavior; this could be considered a multisignaling process (Segovia \& Guillamón, 1993; Segovia et al., 1991, 1996, 1999).

Of the remaining two research trends, one examines the effects of chronic protein malnutrition and administration of cortisol in gestating rats on the development of the nervous system and behavior of the pups (Vicente, Rodríguez Pérez, \& Gómez-Jarabo, 1991; Rodríguez Pérez, Vicente, \& Gómez-Jarabo, 1992).

The last research trend studies the development of the dopaminergic neurons and their influence in motor lateralization in rats (Alfonso, Santana, \& Rodriguez, 1993) as well as the asymmetric distribution of these neurons in the nervous system. The influence of maternal ingestion of tyrosine is assessed, with special focus on the role of melatonin, its synthesis in rat and hamster pineal gland and its function in their estrous cycle (Santana et al., 1994).

In the Learning and Memory section, two research trends also related to the development and plasticity of the nervous system are presented in more detail: one that focuses on neural plasticity in learning (Salas, Rodríguez, Vargas, Durán, \& Torres, 1996), and another that studies the development of the structures involved in spatial orientation behavior (Cimadevilla et al., 1999).

\section{Emotion and Stress}

Studies of the emotional processes are a good example of the diversity of approaches that characterize research in psychobiology. Of the 11 research trends presented in this section, some work with animals (rat or mouse), cartying out neuroendocrine manipulations, pharmacological treatments, or psychogenetic characterizations. Other works focus on emotion in humans, involving sensory processing of emotional stimuli, emotional disorders such as schizophrenia or obsessive-compulsive disorders, or the interrelations of biological aspects and social context.

Starting with the most basic research trends, in the first one, a behavioral and neurochemical characterization was carried out in Roman high-avoidance (RHA: hypoemotional) and Roman low-avoidance (RLA; hyperemotional) rat strains (Fernández-Teruel, Escorihuela, Castellano, González, \& Tobeña, 1997), which have been psychogenetically selected for speed or incapacity (respectively) to acquire two-way active avoidance in the shuttlebox, since the late $60 \mathrm{~s}$. As a 
consequence of this selection, the RLA rats (compared with the RHA) present more anxiety and stress responses in various experimental situations, as well as a lower central GABAergic function, lower mesolymbic dopaminergic function and higher colinergic hippocampal function. The short- and long-term effects of infantile/juvenile stimulation procedures in both strains of rats was also studied, observing that, out of the many variables examined, postnatal stimulation attenuates/eliminates these psychogenetic differences (Escorihuela, Tobeña, \& Femández-Teruel, 1995).

The following three research trends are classified within psychoendocrinology: In two of them, the authors are working on experimental rodent models, and in the third, they are studying high competition sportspeople. The first trend studies the biological bases of individual differences, especially emotion-related aspects, manipulating the thyroid axis activity in rat (Darbra et al., 1995; Martí-Carbonell, Sanz, Darbra, Garau, \& Balada, 1993). The principal results ate: (a) validation of a nonaggressive method of dysthyroidism induction; (b) behavioral characterization of dysthyroidism as a function of the affected period; and (c) characterization of the effects of dysthyroidism, originating in puberty, on the morphology of the pyramidal neurons of the hippocampus (area CA3).

A second research trend studies the effects of various testosterone by-products on agonistic behavior in mice, and the modulating role of various stimulus conditions (aggression-induction model, opponent cype, etc.) (MartinezSanchís, Brain, Salvador, \& Simón, 1996; Martínez-Sanchís, Salvador, Moya-Albiol, González-Bono, \& Simón, 1998). In addition to testosterone propionate, these authors have also used decanoate of nandrolone, Stanozolol, and their combinations. These hormonal by-products have become abuse-substances in various population groups, and important psychological and behavioral effects have been described, including increased aggressive and violent behavior, both in men and women. On the basis of this information, a hypothesis of addiction to these substances, due to the reinforcing properties of testosterone, has been proposed.

The third research trend within the psychoendocrinology area examines the effects of agonistic encounters on men's and women's testosterone and cortisol levels. Competition sports have been used as a standardized situation presenting significant advantages to achieve this goal. The results have shown the relevance of experience and of situational factors in the hormonal response to competitive stress. The roles of physical effort during competition and of sportsmen's physical condition in the hormonal response have been specified. These aspects had not been analyzed in depth in previous research although they had been pointed out (Suay et al., 1996). With regard to this, there have been some publications on the hormonal and psychological effects of physical effort and other laboratory stressors (Sanchís, Suay, Valverde, \& Salvador, 1997).

Three research trends investigate the field of psychoneuroimmunology, using rodent models, and examine the effects of stress on various parameters of immunologic activity. The first trend also studies the neuroendocrine mediators involved in this relationship, using two types of stress: social stress and chronic mild stress (Azpiroz, Arregui, Fano, Garmendia, \& Sánchez-Martín, 1994; Azpíroz, et al., 1999).

A second trend examines whether different behavioral capacities to cope with stressful situations may be related to the functional capacity of the immune system in rats (in strains selected for their learning capacity in active avoidance tests) (Sandi, Castanon, Vitiello, Neveu, \& Mormède, 1991). The authors found that different functionality indexes of the $T$ lymphocytes (proliferation, cytotoxicity of the natural killer [NK] cells) are remarkably different between strains. This indicates that possibly some of the genetic factors responsible for coping behaviors are either related to factors involved in the functionality of the $\mathrm{T}$ lymphocytes or that both factors were genetically co-selected. The effect of the various stress hormones on the proliferation capacity of the spleen lymphocytes is also examined in vitro.

The third research trend that addresses the stressimmunity relationship with experimental models in laboratory animals (rats and mice of different strains) has used surgical stress models (laparotomies), chemical stress models (stresslike drugs such as amphetamines and cocaine), and psychosocial stress models (noise stress patterns). The works evaluate the influence of the stress patterns on various measurement parameters of the immunologic state, both quantitative parameters and indicators of the functional state, (quantification of T and B lymphocytes, cellularity of spleen and thymus gland, proliferate response 10 mytogens, in vivo and in vitro phagocytic activity, cytotoxic activity $-\mathrm{NK}$ activity and generation of cytotoxic $T$ lymphocytes [CTL]-, the retarded hypersensitivy response (DTH), and others), and the possibility of reversing the effects of stress on the immune system by pharmacological means. Within this trend, the effects of the various models of stress on the development of different pathological processes, such as tumors and infectious diseases, have also been studied (Freire-Garabal et al, 1996, 1998).

There are four more research trends within the Emotion section. They all examine emotion in humans. In two of them, aggressiveness is studied from a biopsychosocial perspective and in the other two, some aspects of expressing and processing emotions are examined.

In the Community of Valencia, female victims of domestic violence, the consequences of this stressful situation on their mental and physical health, and on the hormone system, are being studied (Martínez \& Botella, 1996).

In another research trend, the modulating role of context in the manifestation of aggressive behaviors is examined. The authors study the interrelation between aggressionrelated psychological variables such as impulsivity, assertiveness, dominance, and fear, on the one hand, and, on the other, biological variables such as hormonal levels, 
sexual dimorphism, and developmental psychobiological characteristics. The possible predicting value of specific variables is addressed in the analysis of this multidirectional interrelationship, as well as possible modulating variables that might explain the observed variability (Ramirez, 1993, 1998).

Brain activity associated with processing of emotional visual stimuli is studied using electrophysiological measurements (Carretié, Iglesias, \& García, 1997). The authors describe how activity produced between 200 and $300 \mathrm{~ms}$ is mainly associated with the valence (positivenegative) of stimulation (Carretié, Iglesias, \& Bardo, 1998) and how subsequent brain activity is related to the activating or relaxing consequences of the stimulation. They have also observed that response to negative stimuli activates the faster dorsal visual pathway, and that positive stimuli activate the ventral visual pathway, which processes more slowly but more precisely. These data coincide with the results of behavioral studies in which shorter reaction times to negative stimuli have been observed.

In addition to processing of visual emotional stimuli, facial expression and recognition of emotions in infants has also been studied. An exchange of smiles in the motherchild relationship, visual discrimination, and recognition of expressions of fear, anger, and surprise have been observed (Carretié \& Iglesias, 1995; Serrano, Iglesias, \& Loeches, 1992),

In the Development and Plasticity of the nervous system section, we mentioned a research trend that examines the effects of prenatal stress on the differentiation of the vomeronasal system (Cerro et al., 1995) and in the Learning and Memory section, the influence of stress on these processes was described (Sandi et al, 1997).

\section{Ethology}

Among the psychobiologists of the Spanish universities, there is a group of professors who are specialized in ethology. The research conducted by these professors has produced five research trends, four of which have studied basically primates, both in captivity and in natural conditions, and a fifth research trend studies behavior patterns in social fish.

One research trend is studying the capacity of selfawareness in nonhuman primates, more specifically, in captive gorillas and otangutans. Researchers are trying to verify whether these primates are capable of recognizing their own mirror-image, evaluating their spontaneous behaviors and administering the Gallup test (the mark test). This study is especially important because, to date, selfrecognition has been demonstrated in chimpanzees and bonobos, but the wotks carried out by other research groups with gorillas reveal controversial results and the data with orangutans proceed from very small samples (Colell, Segarra, \& Sabater Pi, 1995a, 1995b).
A second line focuses on the way (how and why questions) group-living individuals initiate, mantain, and terminate their social relationships, which involve an interplay of cooperation, competition, and affiliation. Observational and longitudinal studies were carried out focusing on the fine-grained analysis of interaction and communication patterns in well-established social and sociodemographic contexts. The major aim has been the uncovering of behavioral and psychological principles underlying the organization of social systems (Colmenares, 1991, 1992).

A third group of researchers has carried out observations of reproductive and parenting behavior in Calitricides, both in natural situations and in captive animals. They have essentially addressed the study of environmental factors that affect ovulatory suppression; in Saguinus oedipus, costs of cooperation are analyzed; in free-ranging Papio $h$. hamadryas, work is being carried out on their demographic distribution and sociology in Eritrea (Gil-Burmann, Pelaez, \& Sánchez, 1998; Zinner \& Pelaez, 1999).

A fourth research trend studies behaviors, such as nestbuilding or food-gathering, of chimpanzees (Pan paniscus) in natural conditions (Sabater Pi, Vea, \& Serrallonga, 1997; Vea \& Sabater Pi, 1998).

In the fifth research trend, the social organization and the mechanisms of dominance and formation of hierarchies in angel fish is being studied. Changes in behavior in these subjects, occurring as a consequence of the experimental manipulation required to submit them to individual testing, are also being observed (Gómez-Laplaza \& Morgan, 1993).

\section{Neuropsychology}

The field of neuropsychology, with 21 research trends, includes the largest number of researchers among the Psychobiology professors considered in this study. Most of the trends are focused on neuropsychological functions in humans and their developmental and involutional aspects. These processes are studied from the viewpoints of clinical as well as basic research. We have maintained the classical division between basic and clinical neuropsychology, first presenting the six trends that study normal populations, and then, the following 12 trends, which address pathologies or their evaluation. Lastly, we included three trends that offer animal models of neuropsychological pathologies, and a final trend in which a cytogenetic study in subjects with Turner's syndrome is presented, although, these works could be included in the area of basic research, because of their method or the subjects they study.

We shall start with the description of the six research trends using normal populations. In the first trend, within the field of what we could call developmental neuropsychology, researchers are working on the evaluation of neuromaturational development in healthy preschool children, with special attention to children with cerebral dysfunction. Fruit of this 
trend was the development of the "Cuestionario de Madurez Neuropsicológica Infantil" (CUMANIN [Children's Neuropsychological Maturity Questionnaire]; Portellano, Mateos, \& Martínez Arias, 2000), standardized with an extensive Spanish sample of boys and girls between 3 and 6 years of age. In addition to the healthy population, neuropsychological alterations are studied in other infantile populations, such as children with diabetes, children with growth hormone deficit, or preterm children with low body weight at birth (Portellano, Mateos, Valle, \& Aizcun, 1997).

A second research trend has focused on changes in physiological variables such as heart rate, blood pressure, and electrodermal activity in anxiety-provoking situations, attention tasks, or in association with the menstrual cycle. Therapeutic approaches have also been examined to favor modification of physiological variables observed during anxiety- or stress-provoking situations (Gómez Amor, Martínez-Selva, Román, \& Zamora, 1990; Gómez Amor, Martínez Selva, Román, Zamora, \& Sastre, 1990).

Using the event-related potential technique, a third research trend has studied sensory perceptive processes and attentional and memory processes in healthy subjects. The sample included persons aged between 20 and 86 years, male and female, of comparable socioeconomic and cultural levels. The aim of these studies was to characterize the agerelaced changes observed in these subjects in these processes (Amenedo \& Díaz, 1998, 1999).

Other electrophysiological studies broach bidimensional visuo-spatial information processing and the cortical areas involved. Working memory and semantic processing may be reflected in the "recognition potential," a component assumed to be crucial to evaluate reading problems (Martín-Loeches, Gómez-Jarabo, \& Rubia, 1994; Martín-Loeches, Valdés, Gómez-Jarabo, \& Rubia, 1998).

In the $5^{\text {th }}$ and $6^{\text {th }}$ research trends, the study of asymmetries in cognitive functions is addressed. The $5^{\text {th }}$ trend focuses on changes in neuropsychological performance and neurophysiological activity (computerized EEG) induced by autogenous relaxation in left- and right-handed adults. The physiological and cognitive effects of stradiol on brain asymmetry in healthy women were also studied (León \& Portellano, 1999; Portellano \& Robles, 1998).

The $6^{\text {th }}$ research trend addresses brain asymmetry in linguistic and visual processing, in order to explore the relative degree of brain asymmetry. Specifically, the authors focused on the parameters that modulate participation of the right hemisphere in language and the lateralization of object visual recognition (Nieto, Hernández, González-Feria, \& Barroso, 1990; Nieto, Santacruz, Hernández, CamachoRosales, \& Barroso, 1999).

Within the field of clinical neuropsychology, we have identified 12 research trends that study human populations with various disorders. The last one also studies primates. Of these 12 trends, the first three examine various consequences of brain lesions; the following three trends compare pathological aging in with normal aging. Trends 7,8 , and 9 provide clinical evaluation instruments. Lastly, trends 10, 11, and 12 are within the area of cronobiology and are therefore presented together, although some of them are not strictly clinical neuropsychology.

Within the trends studying subjects with brain lesions, in the first one, researchers are examining the long-term consequences of brain lesions in infancy. Their interest is to determine the cerebral plasticity of the immature brain, considering intra- and interhemispheric cerebral reorganization after a brain lesion. The relationship was analyzed between maturing factors (age at trauma), brain lesions detected by magnetic resonance (MR), and chronic neuropyschological deficit. The authors' conclusions clearly differentiate between cortical and subcortical macro-lesions. This research has legal and clinical repercussions and raises doubts about the widespread concept of genuine recovery from lesions in infancy (Junqué \& Vendrell, 1997; Mataró \& Junqué, 1998).

A second research trend studies functional reorganization after focal brain injuries. After such an injury, various neurophysiological phenomena occur that explain why functional damage is more pronounced than structural damage and why, in the following months, partial spontaneous recovery of the cognitive functions is observed. These phenomena are ischemic penumbra, diaschisis, and transneural degeneration, and neuroimaging techniques are currently being used to investigate them. Longitudinal studies, employing SPECT, MR, and neuropsychological measurements, are used to investigate how the injured brain reorganizes itself, after a first episode of focal injury due to ischemic infarct or hemorrhage, with special focus on intrahemispheric cortical-subcortical reorganization and also interhemispheric reorganization (Jurado, Bartomeus, \& Junqué, 1993; Pringatano et al., 1998).

Another group of researchers has analyzed, quantitatively and qualitatively, functional alterations related to focal neurological pathology (in general, cerebral infarcts and tumors) and to diffuse neurological pathology (dementia). This trend offers a method to explore apraxias taking into account the differences or similarities of various voluntary movements (with and without meaning; the use of objects, traditional symbols), and also the modality in which gestures are made (verbal command, imitation, real use of objects). It also offers a qualitative study of the different types of responses made by subjects, which facilitates analyzing the mechanisms underlying apraxias (Mozaz, Martí, Carrera, \& De La Puente, 1990; Mozaz, Peña, Bartaquer, Martí, \& Goldstein, 1993).

Comparison of normal aging and dementia is another focus point among our university neuropsychologists. Junqué and colleagues are working on a model that combines genetic factors and structural and functional degeneration. They hypothesize that there are three ways of normal brain aging that apparently share part of the cerebral and functional degeneration of Parkinson's disease, subcortical vascular 
dementia, and Alzheimer's disease. An attempt is made to relate genetic factors with the way people age. The determination of Apo E and ACE alleles in a extensive sample of normal elderly individuals may be an indication of genetic contribution to the subtypes of "normal" aging. Thus, the presence of Apo E alleles 4 may be related to marked degeneration of the hippocampus (a form of memory loss similar to Alzheimer's disease) and ACE may be related to vascular factors that produce silent infarcts in the white matter (similar to vascular subcortical dementia) (Pujol, Junqué, Vendrell, Grau, \& Capdevila, 1992; Vendrell, Pujol, Junqué, \& Martí-Vilalta, 1995).

A second research trend focuses on neuropsychological and differential diagnosis of the various subtypes of dementia (Perea \& Ladera, 1997a, 1997b), evaluating the deterioration of cognitive processes. These authors are especially interested in the executive function and several of its aspects (attentional direction, hierarchy recognition, expressing intentions, etc.).

And a third trend examines the neuropsychological effects of neurodegenerative processes. Specifically, it explores how cognitive processes are affected in demyelination pathology (multiple sclerosis), degenerative cerebellar pathology (hereditary cerebellar ataxias), and in normal aging (Barroso, Nieto, Olivares, Wollmann, \& Hernández, 2000; Nieto, Barroso, Olivares, Wollman, \& Hemández, 1996).

In the field of neuropsychological evaluation, a group of authors has designed general evaluation scales and specific syndrome scales (aphasia, amnesia, posttraumatic syndrome, etc.) for prognosis in everyday clinical psychology and in cognitive rehabilitation (Perea, Ladera, Blanco, \& Morales, 1999).

The mismatch negativity (MMN) component has been proposed as a clinical instrument for physiological evaluation of the auditory cognitive functions, because it is obtained independently of the subject's attention. This component may be an electrophysiological indicator of functional integrity of the brain mechanisms of attention and sensory memory in Alzheimer's disease, coma, or neurodevelopmental disorders (Grau, Escera, Yago, \& Polo, 1998; Polo, Escera, Gual, \& Grau, 1999).

Another trend is investigating, using event-related potentials, the neurofunctional alterations associated with sensory and cognitive deficits observed in mentally retarded children of various organic and cultural-familial etiologies (Díaz \& Zurrón, 1995; Zurrón \& Díaz, 1995).

The following three research trends belong to the field of cronobiology. The first trend studies sleep disorders that present excessive daytime somnolence (EDS). The authors attempt to determine the pattern of neuropsychological alterations- cognitive deficits and psychopathological disorders - specifically associated with each of the main EDS disorders: sleep apnea syndrome (SAS), narcolepsycataplexy syndrome, and psychiatric hypersomnia. Evaluation of long-term effects of continuous positive airway pressure (CPAP) treatment on various types of cognitive deficits and the level of psychosocial adaptation of SAS patients is addressed. The relative contribution of etiological factors (apnea index, degree of nocturnal hypoxemia, and anomalies in the architecture of sleep) to the pathogenesis of these cognitive deficits in SAS patients is also examined (Ramos Platón \& Espinar Sierra, 1992).

Other biological rhythms in addition to sleep have also been studied. The second research trend describes ultradian rhythms in spontaneous activity of awake human adults, using an interval similar to the interREM sleep intervals (1 1 1/2 hours) (Grau et al., 1995).

In a third trend, researchers have studied circadian organization, temperature, and sleep in primates, in an attempt to establish animal models of neuropsychological pathologies. The relationship between body temperature and activity, both in normal and in pathological situations, has been examined. The relationship between circadian rhythms and ultradian and seasonal rhythms has aiso been studied. The following resuits are noted: (a) description of the evolution of temperature during sleep; (b) verification of sex differences in thermolytic mechanisms; (c) study of circadian organization in an experimental model of Parkinson's disease (Almirall et al., 1993; Almirall, Nicolau, Gamundi, Roselló, \& Rial, 1997).

We will now describe three research trends, the inclusion of which in the specific Neuropsychology section might be arguable, but which have been included here to avoid more divisions. The first trend presents an experimental model of hepatic encephalopathy caused by portacaval shunt that provokes cirrhosis and gives rise to encephalopathy in the CNS. This model has allowed the research group to detect similar alterations to those found in humans, in circulating megacariocytes, in Alzheimer type-II cells, and in behavioral changes, mainly biorhythms (Arias, Alsasua, Aller, Lorente, \& Arias, 1993; López et al., 1997).

A second trend included in the psychogenetic field focuses on the research of new ways to study Down's syndrome from a neurobiological approach. The first complete behavioral assessment of Ts65Dn mice (with partial trisomy of the 16chromosone) has been carried out. This is currently the best model of human Down's syndrome. Sensory, motor and exploratory behavior, anxiety, spatial learning, and other cognitive abilities (short- and long-term memory, 'working memory') have been tested, as well as the influence of certain experiences on subsequent performance of specific tasks (Escorihuela, Fernández-Teruel, et al., 1995; Escorihuela, Valliina et al., 1998). In addition to the data obtained about neuromorphological and neurochemical aspects of Ts65Dn mice, this characterization has revealed new perspectives in neurobiological research on Down's syndrome.

In the third research trend, a cytogenetic and behavioral study of individuals with Turner's syndrome was undertaken. The characteristics of the X-chromosome associated with this syndrome were studied (Fernández Méndez, \& Pásaro, 1996; Pásaro, Fernández, \& Méndez, 1993). 
In addition to the 21 research trends described in the Neuropsychology section, another interesting trend, which has established experimental models of amnesia and memory retrieval and facilitation in rats, is described in the Leaming and Memory section.

\section{Sensory Processing}

A small number of Psychobiology professors investigate sensory processing, focusing on the auditory and visual modalities. Of the five research trends described here, three of them study attention-related sensory processing using electrophysiological recordings, and the remaining two trends examine the evaluation of sensory processing within a species, using comparison of electrophysiological recordings and other physiological and behavioral techniques.

The first trend addresses brain mechanisms in auditory cognition. The research group has studied conscious auditory perception, auditory sensory memory, and involuntary auditory attention using event-related potential recordings in combination with other techniques. By means of the mismatch negativity (MMN) that is generated in the supratemporal cortex when a repetitious stimulation changes (Escera, Alho, Winkler, \& Näatänen, 1998), the authors have established the existence of two differentiated brain mechanisms to capture involuntary attention. They have also established that the $\mathrm{Hl}$-histamine-receptor may be involved in mismatch negativity (Serra, Escera, Sánchez-Turet, Sánchez Sastre, \& Grau, 1996).

The processing of task-irrelevant stimulation centers the interest of a second research trend. More specifically, the Simon effect (i.e., spatial compatibility effects when stimulus location is irrelevant) (Valle-Inclán, 1996) and the accessory effect (i.e., faster reactions when visual stimuli are accompanied by an irrelevant auditory stimulation) (Hackley \& Valle-Inclán, 1998) have been investigated. The research on the Simon effect concludes that interference during response selection is critical for the Simon effect to appear, but it is dubious whether this process should be considered automatic. The results with the accessory effect indicate that it is produced before response selection is over, which ends a long controversy about the locus of the accessory effect.

In a third research trend, event-related potentials in combination with localization techniques and frequency analysis have been recorded to study spatial visual attention. It has been pointed out that the $\mathrm{Cl}$ component is localized in the striate cortex, and that attentional modulation begins in extrastriate areas; alpha rhythm attenuation and beta rhythm increment have also been observed during these tasks (Gómez, Clark, Fan, Luck, \& Hillyard, 1994). Applying the gap paradigm to study motor attention, the following results are reported: (a) the gap effect is robust and it appears in visual and auditory modalities, both in manual and ocular responses; (b) unfocused attention and preparation for movement may contribute to the gap effect; (c) event-related potentials suggest processes both of sensory gap recording and of preparation for movement (Gômez, Atienza, LópezMendoza, \& Vázquez, 1995). These authors have also determined some components of electrophysiological recordings associated with sensory memory in different states of arousal, and with face processing, ambiguous figures, etc. (Atienza, Cantero, \& Gómez, 1997).

The next two research trends focus on the visual function of a species. The characterization of the visual function of a species is important because, on the one hand, it provides knowledge about how visual processing is achieved and how the visual systcm became established at a ccrtain point of the phylogenetic scale. On the other hand, it offer's a model to evaluate the effects of experimental manipulations on a species, and the disorders that affect that species. Two groups of Spanish psychobiologists work in this area.

In invertebrates, one group studies guided visual behavior in the arthropod Lycosa tarentula (Araneate, Lycosidae), and have established the continuity between morphological, physiological, and behavioral aspects of the orientation capacity of this spider using polarized light (Kovoor, MuñozCuevas, \& Ortega-Escobar 1993; Ortega-Escobar \& MuñozCuevas, 1999).

In the fifth and last research trend of this section, the authors developed a model to evaluate the visual function in rats and mice, the two most frequently used species in research. In the study on visual acuity, measurements of the optical quality of the retinal image were compared with the thresholds estimated from cortical EPs, and with behavioral measurements. In the study on luminance, electrophysiological thresholds (with recordings of electroretinogram, event-related cortical potentials (EP) and EPs in the superior colliculus) and behavioral and pupillary thresholds were obtained. This model may be very useful for early detection and diagnosis of visual function alterations, as has been revealed in the study of albino subjects (Herreros de Tejada, Green, \& Muñoz Tedó, 1992; Herreros de Tejada, Muñoz Tedó, \& Costi, 1997).

In this section, five research trends were described. In the Emotion section, a more detailed description can be found of another trend that also addresses some aspects of sensory processing, specifically emotional stimulus processing, implying the dorsal and ventral visual pathways with the negative or positive valence of the sensory stimulus (Carretié, Iglesias, \& Bardo, 1998).

\section{Psychophamacology}

The greatest amount of research appears in this field, along with Neuropsychology. We have identified 15 research trends, of which many (eight) focus on the study of abusedrugs and addictive behavior, which are topics of great social impact. Of these cight trends, five study alcoholism. The remaining seven trends study the effects of certain psychoactive drugs, both in the clinical field and in the development of animal models. 
Abuse-drugs form part of a small number of substances that are chemically quite distinct from each other, but that are capable of altering an individual's emotional and motivational state drastically. In the first trend, the control of the neurobiological substrates involved in these processes is studied in experimental rodent models. In addition, possible psychopharmaceutical strategies capable of reversing the action of drugs are being developed (Navarro, Rubio, \& Rodríguez de Fonseca, 1995; Rodríguez de Fonseca, Carrera, Navarro, Koob, \& Weiss, 1997).

The second trend addresses the role of the dopaminergic system in the generation of the reinforcing effects of abuse substances and of excitatory amino acids that are possibly involved in the addictive mechanism of opiates. Locationpreference conditioning is used to study the reinforcing properties (dependence) of these systems, whereas to study the aversive properties (abstinence syndrome), aversive location conditioning is used. The authors also analyze the role of the nucleus accumbens and the prefrontal cortex, both in the development of dependence and in the conditioned effects of the abstinence syndrome of morphine (Aguilar, Mari-Sanmillán, Morant-Deusa, \& Miñarro, 2000; Rodríguez-Arias, Miñarro, Aguilar, Pinazo, \& Simón, 1998).

The third trend examines the reinforcement mechanisms (cellular mechanisms and systems mechanisms) of opiates and cocaine. Self-administration of abuse-drugs (morphine and cocaine) and their relation with spontaneous motor activity and cardiovascular effects were investigated in rats. The interaction mechanisms of opiate receptors, their reinforcing effect, and the modifications due to the action of corticotropin were examined (Ambrosio, Sharpe, \& Pilotte, 1997; Persico, Schindler, Davis, Ambrosio, \& Uhl, 1998).

Studies are undertaken on the possible role of opiate peptides as mediators of the reinforcing action of alcohol and the consequent development of preference for alcohol consumption (Sandi, Borrell, \& Guaza, 1990). For this purpose, in this fourth trend, an experimental paradigm of "preference" with rats was used, following a model of "double choice" between water and ethanol. The session of forced ingestion of ethanol (conditioning session) was revealed to be crucial for the development of ethanol preference. By means of psychopharmacological approximations, the involvement of the opioidergic systems in the development of preference for alcohol consumption was demonstrated.

The next four research trends also study alcoholism. On the basis of their own theory of the process of drug addiction, a group of researchers has developed standardized experimental models of alcoholism (which allow verification of levels of consumption, tolerance, abstinence syndrome, etc.) using unselected albino rats, with which they have studied various addiction-related associative learning paradigms. This group has reported a specific relation between consumption of toxic doses of alcohol and the simple learning of an instrumental response. This has allowed them to contrast various hypotheses about the neuroanatomical substrate of addictions and the cholinergic hypothesis of physiological and molecular changes. The first dose/response studies were carried out about the effects of nicotine and mecamilamine in septal area and hippocampus on learning and the inhibition of appetitive responses, in chronic alcohol-drinking subjects (Nadal, Prat, Pallarés, Hernández-Torres, \& Ferré 1996; Pallarés, Nadal, Hernández-Torres, \& Ferré, 1997).

The enzymatic neural mechanisms induced by ethanol and the behavioral importance of these mechanisms are being examined by manipulating catalase with inhibitors and inductors of this enzyme (Rotzinger, Aragón, Rogan, Amir, \& Amit, 1995; Sanchis-Segura, Miquel, Cortea, \& Aragón, 1999). This has allowed researchers to show that some effects of ethanol seem to require the oxidation of ethanol to acetaldehyde: catalase inhibitors block these effects depending on the dose, whereas inductors enhance them. The localization of this metabolism in the CNS is being studied, because catalase does not seem to be homogeneously distributed in the brain. The behavioral consequences of manipulating the levels of acetaldehyde in the brain are also under study, with pharmacological tools, using sulphurated aminoacids that have been observed to bind acetaldehyde in vivo, and inhibitors of the brain enzyme that metabolizes acetaldehyde (ALDH).

The delimitation of a neurocognitive profile of family vulnerability is another aspect of alcoholism under study in a research trend. Based on studies of genetic epidemiology and models of risk for developing alcoholism, an extensive psychophysiological (EP recordings) and neuropsychological battery was used to identify possible vulnerability markers in children from families with a high density of alcoholism, but who had not yet commenced alcohol ingestion. There is evidence of potentially useful cues that could be tested by means of follow-up studies (Rodríguez Holguín, Corral, \& Cadaveira, 1998a, 1998b).

In chronic alcoholic abstinent patients, neurofunctional deterioration has been evaluated with the EP technique. In this research, short-, medium-, and long-latency visual and auditory EPs were used, as well as endogenous components such as $\mathrm{N} 2, \mathrm{P} 3$, and negative contingent variation (NCV). Except for $\mathrm{NCV}$, the tests have proved to be highly sensitive for assessing the neurotoxic effects of alcohol (Cadaveira, Grau, Roso, \& Sánchez-Turet, 1991). Large individual differences were revealed in the effects of chronic consumption of alcohol, even among persons of similar ages and drinking history. Five-month and 1-year follow-ups of abstinence showed only partial reversibility of the abnormalities (Cadaveira, Corominas, Rodríguez Holguín, Sánchez-Turet, \& Grau, 1994).

We will now describe the seven remaining research trends, all of them focusing on various psychoactive drugs. In the first trend, studies of schizophrenic and obsessive-compulsive patients, and of patients affected with attention-deficit hyperactivity disotder (ADHD) are being conducted, 
addressing the effects of psychoactive drugs in regional brain metabolism and in cognition. These works show structural and functional deficits that indicate an alteration of the anatomic-functional neurodevelopment of the fronto-striatum system. In schizophrenia, frontal basal neurodevelopmental hypofunction was detected; in ADHD, a decreased volume of the frontal lobe was identified, in addition to a larger-thannormal size of the right caudate nucleus. Psychoactive drugs that affect the dopaminergetic system produce changes in the basal ganglia and in the medial prefrontal cortex that are detectable by means of magnetic resonance. Neurochemical analysis in vivo, along with the analysis of therapeutic response and cognitive changes, may improve clinical psychiatric practice (Mataix et al., 1997; Verger, Junqué, García, Pardo, \& Martí-Vilalta, 1996).

In the second trend, in addition to an epidetniological study in a mental health center, research on psychopathological disorders, such as panic and aggression, and possible psychotherapeutic and psychopharmacological treatments was catried out (López Alonso \& Gómez-Jarabo, 2000).

In the third trend, animal models are used to study the dopaminergic system (Navarro, Miñarro \& Simón, 1993), GABA, and other neurotransmitters such as opioids, nitrous oxide, and adenosine (Espert, Navarro, Salvador, \& Simón, 1993) in aggressive behavior. The role of the GABA system in the regulation of other behaviors is also examined.

The effects of various psychoactive drugs on agonistic behavior in mice were studied, using a behavior assessment program to examine the variations in several behavior categories and patterns. In this fourth trend, this technique was applied to the study of representative substances of the main groups of psychoactive drugs: antidepressants, psychostimulants, anxiolytics, and opioids. The effect on agonistic behavior of some stimulus conditions, such as the type of opponent, repeated fighting experience, and the model of induced aggression were also analyzed (Martínez, Salvador, \& Simón, 1994; Moro, Salvador, \& Simón, 1997).

Another group of researchers is carrying out pharmacological studies about the effect of diazepam, buspirone, and chlorpromazine, and other psychoactive drugs on active avoidance learning (Morales, Torres, Megías, Cándido, \& Maldonado, 1992; Torres, Morales, Cándido, \& Maldonado, 1996).

In the sixth trend, sex differences in the effects of neuroleptic drugs on escape-avoidance behavior in mice are studied. The acute administration of haloperidol, raclopride, clozapine, and SCH 23390, impaired escape-avoidance behavior, more in males than in females, and the subchronic administration of haloperidol had a similar effect. This appeared to be a reliable phenomenon, because it was observed in both kinds of administration, in two mouse strains, and with several drugs and doses. The observed results were dose dependent. The sex differences in escapeavoidance did not seem related to sex differences in the well-known deteriorating effects of these drugs on motor activity. In addition, an analysis of these studies showed that there were no sex differences in the variability of responses, reinforcing the idea that female subjects should be included in these types of studies (Parra, Arenas, Monteón, Vinader-Caerols, \& Simón, 1999).

The identification of the endocannabinoid system as a new system of sinaptic communication and neural signaling was a very important neurobiological event in the nineties. This system is involved in the control of motor behavior and in various neuropsychiatric disorders. One of the teams of psychobiologists has centered its work on identifying the functional nature of the principal endogenous lipid of the endocannabinoid system and its behavioral relationship (Giuffrida et al., 1999), and the first intemational monograph on this system has been published (Rodríguez de Fonseca, del Arco, Martín-Calderón, Gorriti, \& Navarro, 1998).

In the Emotion section, we described an interesting psychopharmacology-telated trend, in which researchers are using testosterone by-products, hypothesizing addiction to these substances because of the reinforcing properties of testosterone (Martínez-Sanchís et al., 1998).

\section{Conclusions}

This work is the result of the study of research published by Psychobiology professors from 1989 to 1998 . Only tenured professors were considered, totaling 110 professors from 19 universities. The total list of publications includes 904 different articles. 1429 Psychobiology professors cosign these 904 articles. The results of these investigations are described in what we have called research trends, which, in turn are grouped into specific research areas to facilitate follow-up and presentation of a panorama of the content of the Psychobiology publications.

\section{Scientific Prodaction}

For each professor, the rate of scientific production taken into account is an average of 13 quotations. Perhaps this average is not very representative due to the large individual variation in the number of publications -from 1 to 92 quotations-among the researchers. Similarly, it could be concluded that the whole rate of quotations from the decade is contaminated, because, taking into account the list of professors (the University Council List of April 7, 1999) who achieved tenure between 1979 (when the first psychobiology professor achieved tenure) and 1999, some researchers' publications do not correspond to 10 years of work with tenure, but rather to shorter intervals. We also point out that, in this decade, only $15 \%$ of the professors have published less than 5 articles, and the professors whom we could not contact after the first letter belong to this $15 \%$. Therefore, these latter professors may have publications not reflected in this article. 
Essentially, when a professor joins the University, his or her researching trajectory is evaluated. Professors who have worked before their access to tenure in research centers have had more opportunities to publish than have untenured teachers (teachers hired by the University), who must teach and investigate simultaneously. In Figure $1 \mathrm{~B}$ can be seen the mismatch between the quantity of students, whose classes are often taught by untenured teachers, and the number of tenured professors. We must therefore emphasize that the proportion of publications per researcher is very high, especially taking into account that, in most Spanish universities, researchers can only spend part of their time investigating because they must dedicate up to 240 hours per year to presential classes, obviously in addition to the time spent in personalized attention to students. This prevents them from working in the laboratories during the instruction period; they also usually have only one sabbatical period in their lives.

Lastly, we must take into account that Psychology Faculties (Psychology Centers) are often quite recent and, therefore, in the ten years considered, new Study Plans have been developed, with the corresponding organization of the curricular content of Psychobiology (compulsory in all Universities) and, especially, mounting the research laboratories in the faculties and obtaining the necessary funds. Psychobiology laboratories require high-tech instrumentation, which, in general, means large investments for Psychology Faculties.

As a general overview of these comments, in Figure 3 can be seen the total number of quotations in the 89-98 decade, corresponding to the professors from the list employed (the University Council List of April 7, 1999),

No. of professors

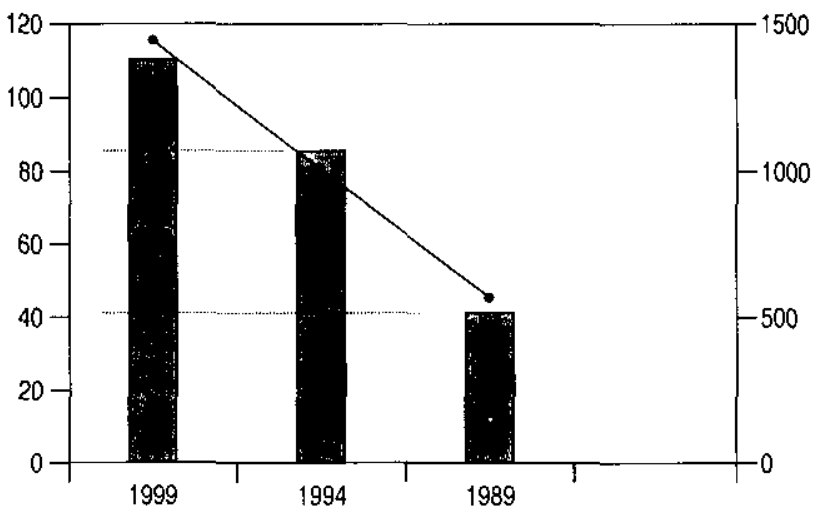

Figure 3. Number of Psychobiology professors, from the list studied in this work, according to the date of their access to tenure between the years 1989-1999.

Bars / Left Y Axis: Number of professors according to the date of their access to tenure. Black circles / Right Y Axis: Total number of quotations during the 89-98 decade of the group of corresponding professors. $X$ Axis: Deadline for access to tenure (see text). separated into 3 groups according to the dates when they achieved tenure. The first bar represents the 110 professors from the list, who achieved tenure between 1979 and 1999 ; the black circle corresponds to the 1429 quotations during the 10 years. The second bar corresponds to the group of 85 professors who had tenure in 1994 (mid-point of the decade under study); and the circle represents the total number of quotations (1015) by this group during the decade. The third bar represents the professors who already had tenure (42) at the beginning of the period under study (1989) and the circle represents the total number of corresponding quotations (578). As can be seen in the data of this chart, out of the professors from the list, $38 \%$ already had tenure in 1989 , another $39 \%$ were tenured during the first 5-year period, and the remaining $23 \%$ during the second 5-year period.

\section{Specific Research Areas}

With regard to grouping the research trends into specific research areas, no doubt there could have been more sections, or the sections included could have been divided into subsections. For example, the research trends included in Emotion could be divided into specific subareas, such as Psychoendocrinology, Psychoimmunology, etc. On the other hand, the broad range of publications of the same research trend would allow classifying them into more than one specific area. Because of this, we decided that grouping the works into large areas would help readers to get a panoramic overview of the works. In Figure 2 can be seen the specific areas described, the number of research trends included in each of them, and the number of University Council List professors who participated in the studies in each area.

\section{International Dissemination}

The languages used preferentially in the 904 publications taken into account are English (74.7\%) and Spanish (24.8\%); in the remaining articles, less than $1 \%$, other languages with less dissemination in our scientific setting (Japanese, German, Catalan, etc.) were used. The percentage of almost $75 \%$ indicates a high rate of communication of results, since English is currently the language of the scientific community. Regarding the journals in which the articles were published, in the bibliography selected as references of the research trends, one can find a high percentage of international journals, some with maximum publication requirements. In some cases, these publications correspond to cooperation with foreign research groups, and in others, to works carried out by only-Spanish groups. Readers are reminded that the need to defend and publish works in international journals is an additional toll for research in our universities, and the only way to avoid scientific isolation and to achieve international dissemination of the results obtained. 
Lastly, it is noteworthy that in this decade, the achievements of research in Psychobiology in Spanish universities have improved greatly, partially because of the increase in the proportion of researchers and, especially, the high impact of the journals in which the articles are published. Although the impact of these journals is another indication of the possible quality of the content of the publications, in the evaluation of the research contributed by Psychobiology professors in this decade, without a doubt, the content is more important than the amount, and we have tried to emphasize this aspect in this study.

Looking at the future of research in Psychobiology, we wish to point out that the number of publications and the number of high-impact publications have both increased in the last years of this decade. In addition, almost all the professors have mentioned that their 1999 publications and their projects for the year 2000 were of better quality than those of 1998, and this can be considered an indication of growth and improvement in the works of the next decade.

\section{References}

Agüero, A., Arnedo, M., Gallo, M., \& Puerto, A. (1993). Lesions of the lateral Parabrachial nuclei disrupt aversion learning induced by electrical stimulation of the area Postrema. Brain Research Bulletin, 30, 585-592.

Agiiero, A., Gallo, M., Arnedo, M., Molina, F., \& Puerto, A. (1996). Effects of lesions of the medial parabrachial nucleus (PBBm): Taste discrimination and lithium-chloride-induced aversion learning after delayed and contiguous interstimulus intervals. Psychobiology, 24, 265-280.

Aguilar, M.A., Mari-Sanmillán, M.I., Morant-Deusa, J.J., \& Miñarro, J. (2000). Different inhibition of CAR by clozapine as well as DA, D1, and D2 antagonists in male mice. Behavioral Neuroscience, 114, 389-400.

Aldavert-Vera, L., Costa-Miserachs, D., Massanés-Rotger, E., Soriano-Mas, C., Segura-Torres. P. \& Morgado-Bernal, I. (1997). Facilitation of a distributed shuttle-box conditioning with posttraining intracranial self-stimulation in old rats. Neurobiology of Learning and Memory, 67, 254-258.

Alfonso, D., Santana, C., Rodríguez, M. (1993). Neonatal lateralization of behavior and brain dopaminergic asymmetry. Brain Research Bulletin, 32, 11-16.

Almirall, H., Aguirre, A., Rial, R.V., Daurat, A., Foret, J., \& Benoit, O. (1993). Temperature drop and sleep: Testing the contribution of SWS in keeping cool. NeuroReport, 5, 177-180.

Almirall, H., Nicolau, M.C., Gamundi, A., Roselló, C., \& Rial, R.V. (1997). Main trends in rectal temperature during sleep. Hypnogram and thermogram. Neuropsychobiology, 35, 8490.

Ambrosio, E., Sharpe, L.G., \& Pilotte, N.S. (1997). Regional binding to corticotropin releasing factor receptors in brain of rats exposed to chronic cocaine and cocaine withdrawal. Synapse, 25, 272-276.
Amenedo, E., \& Díaz, F. (1998). Ageing-related changes in processing of non-target and target stimuli during an auditory oddball task. Biological Psychology, 48, 235-267.

Amenedo, E., \& Díaz, F. (1999). Ageing-related changes in the processing of attended and unattended standard stimuli. NeuroReport, 10, 1-6.

Arias J.L., Alsasua, A., Aller, M., Lorente, L., \& Arias, J. (1993). Metabolism of biogenic amines in experimental portosystemic encephalopathy. Research in Surgery, 5, 150+153.

Amedo, A., Gallo, M., Agüero, A., Molina, F., \& Puerto, A. (1993). Medullary afferent vagal axotomy disnupts $\mathrm{NaCl}$-induced shortterm taste aversion learning. Behavioral and Neural Biology, 59, 69-75.

Atienza, M., Cantero, J.L., Gómez, C.M. (1997). The mismatch negativity component reveals the sensory memory during REM sleep in humans. Neuroscience Letters, 237, 1-4.

Azpiroz, A., Arregui, A., Fano, E., Garmendia, L., \& SánchezMartín J.R. (1994). Fighting experiences and natural killer cell activity in male laboratory mice. Aggressive Behavior, $20,67-72$.

Azpiroz, A., Fano, E., Garmendia, L., Arregi, A., Cacho, R., Goitia G., \& Brain, P.F. (1999). Effects of chronic mild stress (CMS) and imipramine administration, on splen_mononuclear cell proliferative response, serum corticosterone level and brain norepinephrine content in male mice. Psychoneuroendocrinology, 24, 345-362.

Barroso, I., Nieto, A., Olivares, T., Wollmann, T., \& Hernández, M.A. (2000). Evaluación neuropsicológica en la esclerosis múltiple. Revista de Neurología, 30, 985-988.

Cadaveira, F., Corominas, M., Rodríguez Holguín, S., SánchezTuret, M., \& Grau, C. (1994). Reversibility of brain-stem evoked potentials abnormalities in abstinent chronic alcoholics: One year follow-up. Electroencephalography and Clinical Neurophysiology, 90, 450-455.

Cadaveira, F., Grau, C., Roso, M., \& Sánchez-Turet, M. (1991). Multimodality exploration of evoked potentials in chronic alcoholics. Alcoholism: Clinical and Experimental Research, 15, 607-611.

Carretié, L.., \& Iglesias, J. (1995). An ERP study on the specificity of facial expression processing. International Journal of Psychophysiology, 19, 183-192.

Carretié, L., Iglesias, J., \& Bardo, C. (1998). Parietal N300 elicited by emotional visual stimulation. Jountal of Pychophysiology, I2, 376-383.

Carretié, L., Iglesias, J., \& García, T. (1997). A study of the emotional processing of visual stimuli through event-related potentials. Brain and Cognition, 34, 207-217.

Cerro, M.C.R. del ( 1998). Role of the vomeronasal input in maternal behavior. Psychoneuroendocrinology, 23, 905-926.

Cerro, M.C.R del, Jzquierdo, M.A.P., Rosenblatt, J.S., Johnson, B., Pacheco, P., \& Komisaruk, B.R. (1995). Brain activity related to maternal behavior-inducing stimuli in the rat. Brain Research, 696, 213-220.

Cimadevilla, J.M., González-Pardo, H., López, L., Díaz, F., Cueto, E.G., García-Moreno, L.M., \& Arias, J.L. (1999). Sex-related 
differences in spatial learning during the early postnatal development of the rat. Behavioral Processes, 46, 159-171.

Colell, M., Segarra, M.D., \& Sabater Pi, J. (1995a). Hand preferences in chimpanzees (Pan troglodytes), bonobos ( $P$ an paniscus) and orangutans (Pongo Pygmaeus) in food-reaching and other daily activities. Intemational Joumal of Primatology, I6, 413-434.

Colell, M., Segarra, M.D., \& Sabater Pi, J. (1995b). Manual laterality in chimpanzees (Pan troglodytes) in complex tasks. Journal of Comparative Psychology, 109, 298-307.

Collado, P., Segovia, S., Calés, J.M., Pérez-Laso, C., RodríguezZafra, M., Guillamón, A., \& Valencía, A. (1992). Female's DHT controls sex differences in the rat bed nucleus of the accessory offactory tract. NeuroReport, 3, 327-329.

Colmenares, F. (1991). Greeting behaviour between male baboons: Oestrous females, rivalry and negotiation. Animal Behaviour, $41,49-60$.

Colmenares, F. (1992). Clans and harems in a colony of hamadryas and hybrid baboons: Male kinship, familiarity and the formation of brother-teams. Behaviour, 121, 61-94.

Darbra, S., Balada, F., Garau, A., Gatell, P., Sala, J., \& Martí Carbonell, M.A. (1995). Perinatal alterations of thyroid hormones and behaviour in adult rats. Behavioral Brain Research, 68, 159-164.

Díaz, F., \& Zurrón, M. (1995). Auditory evoked potentials in Down's syndrome. Electroencephalography and Clinical Neurophysiology. Evoked Potentials, 96, 526-537.

Escera, C., Alho, K., Winkler, I, \& Näatänen, R. (1998). Neura] mechanisms of involuntary attention to acoustic novelty and change, Journal of Cognitive Neuroscience, 10, 590-604.

Escorihuela, R.M., Fernández-Teruel, A., Vallina, I.F., Baamonde, C., Lumbreras, M., Dierssen, M., Tobeña, A., \& Flórez, J. (1995). A behavioral assessment of Ts65Dn mice: A putative Down syndrome model. Neuroscience Letters, 199, 143 146.

Escorihuela, RM., Tobeña, A., \& Fernández-Teruel, A. (1995). Environmental enrichment and postnatal handling prevent spatial learning deficits in aged hypoemotional (Roman highavoidance) and hyperemotional (Roman low-avoidance) rats. Learning and Memory, 2, 40-48.

Escorihuela, R.M., Vallina, I.F., Martínez-Cue, C., Baamonde, C., Dierssen, M., Tobeña, A., Flórez, J., \& Fernández-Teruel, A. (1998). Impaired short-term and long-term memory in Ts65Dn mice: A model for Down syndrome. Neuroscience Letters, 247, 171-174.

Espert, R., Navarro, J.F., Salvador, A., \& Simón, V.M. (1993). Effects of morphine hydrochloride on social encounters between male mice. Aggressive Behavior, 19, 377-383.

Fernández, J. (this issue). Research trends in Spanish psychology (1989-1998).

Fernández, R., Méndez, J., \& Pásaro, E. (1996). Turner syndrome: A study of chromosomal mosaicism. Human Genetics, 98, 2935.

Fernández-Teruel, A., Escorihuela, R.M., Castellano, B., González, B., \& Tobeña, A. (1997). Neonatal handling and environmental enrichment effects on emotionality, novelty/reward seeking, and age-related cognitive and hippocampal impairments: Focus on the Roman tat lines. Behavior Genetics, 27, 513-526.

Freire-Garabal, M., Núñez-Iglesias, M.J., Losada, C., PereiroRaposo, M.D., Riveiro, P., Fernândez-Rial, J.C., Garcia Vallejo, M., Mayan, J.M., \& Rey-Méndez, M. (1996). Inhibitory effects of buspirone on the enhancement of lung metastases induced by operative stress in rats. Research Communications in Biological Psychology and Psychiatry, 21, 13-25.

Frejre-Garabal, M., Núñez-Iglesias, M.J., Rey-Méndez, M., PereiroRaposo, M.D., Riveiro, P., Fernández-Rial, J.C., Losada, C., Gandoy, M., \& Mayan, J.M. (1998). Effects of amphetamine on the development of Moloney sarcoma virus-induced tumors in mice. Oncology Reports 5, 381-383.

Gallo, M., Márquez, S.L., Ballesteros, M.A., \& Maldonado, A. (1999). Functional blockade of the parabrachial area by tetrodotoxin disrupts the acquisition of conditioned taste aversion induced by motion-sickness in rats. Neuroscience Letters, 265, 57-60.

Gallo, M., Valouskova, V., \& Cándido, A. (1997). Fetal hippocampal transplants restore conditioned blocking in rats with dorsal hippocampal lesions: Effect of age. Behavioral Brain Research, $88,67-74$.

Gil-Burmann, C., Peláez, F., \& Sánchez, S. (1998). Variations in competitive mechanisms of captive male hamadryas-like baboons in two feeding situations. Primates, 39, 473-484.

Giuffrida, A., Parsons, L.H., Kerr, T.M., Rodríguez de Fonseca, F., Navarto, M., \& Piomelli, D. (1999). Dopamine activation of endogenous cannabinoid signaling in dorsal striatum. Nature Neuroscience, 2, 358-363.

Gómez, C., Atienza, M., López-Mendoza, D., \& Vázquez, M. (1995). Cortical potentials associated to visual stimuli and manual responses during gap and non gap paradigms. Neuroscience Letters, 186, 107-110.

Gómez, C., Clark, V.P., Fan, S., Luck, S.J., \& Hillyard, S.A. (1994). Sources of attention-sensitive visual event related potentials. Brain Topography, 7, 41-51.

Gómez-Amor, J., Martínez-Selva, J.M., Román, F., \& Zamora, S. (1990). Electrodermal activity in menstrual cycle phases: A comparison of within- and between-subjects designs. International Journal of Psychophysiology, 9. 39-47.

Gómez-Amor, J, Martínez-Selva, J.M., Román, F., Zamora, S., \& Sastre, J.F. (1990). Electrodermal activity, homonal levels and subjective experience during the menstrual cycle. Biological Psychology, 30, 125-139.

Gómez-Laplaza, L.M., Morgan, E. (1993) Social isolation, aggression, and dominance in attacks in juvenile angelfish, Pterophyllum scalare. Aggressive Behavior, 19, 213-222.

González-González, S., Diaz, F., Vallejo, G., Arias, J.L. (1996). Functional sexual dimorphism of the nucleolar organizer regions in the tuberomamillary nucleus. Brain Research, 736, 1-6.

Grau, C., Escera, C., Cilveti, R., García, M., Fernández, J.R., Mojón, A., \& Hermida, R. (1995). Ultradian rhythms in gross motor activity of adult humans. Physiology and Behavior, 57, $411-419$. 
Grau, C., Escera, C., Yago, E., \& Polo, M.D. (1998). Mismatch negativity and auditory sensory memory evaluation: A new faster paradigm. NeuroReport, 9, 2451-2456.

Guillazo-Blanch, G., Vale-Martínez, A, Martí-Nicolovius, M., CollAndres, M., \& Morgado-Bernal, I. (1999). The parafascicular nucleus and two-way active avoidance: Effects of electrical stimulation and electrode implantation. Experimental Brain Research, I29, 605-614.

Hackley, S.A., \& Valle-Inclán, F. (1998). Automatic alerting does not speed late motoric processes in a reaction time task. Nature, 391, 786-788.

Herreros de Tejada, P., Green D.G., \& Muñoz Tedó, C. (1992). Visual thresholds in albino and pigmented rats. Visual Neuroscience, 9, 409-414.

Herreros de Tejada, P., Muñoz Tedó, C. \& Costi, C. (1997). Behavioral estimates of absolute visual threshold in mice. Vision Research, 37, 2427-2432.

Junqué, C., \& Vendrell, P. (1997). Consecuencias neuropsicológicas de la asfixia perinatal. Acta Luso-Española de Neurología y Psiquiatría, 25, 182-188.

Jurado, M.A., Bartomeus, F., \& Junqué, C. (1993). Secuelas neuropsicológicas en los traumatismos craneoencefálicos. Relación entre el déficit objetivo y el subjetivo. Neurología, 8, 91-98.

Kovoor, J., Muñoz-Cuevas, A., \& Ortega-Escobar, J. (1993). Microanatomy of the anterior median eyes and its possible relation to polarized-light reception in Lycosa tarentula (Araneae, Lycosidae). Bolletino di Zoologia, 60, 367-375.

León, M.I., \& Portellano, J.A. (1999). Depresión infantil: su relación con la lateralidad y la asimetría de las funciones cognitivas. Archivos de Neurobiología, 62, 35-48.

López, L., Burgos, P., Santín, L.J., Begega, A., Arias, J., Lorente, L., \& Arias, J.L. (1997). Portacaval shunt control animals: Physiological consequences derived from the sham operation. Lab Animal, 31, 225-230.

López Alonso, J.C., \& Gómez-Jarabo, G. (2000). A model of therapeutical action in panic disorders. European Journal of Psychiatry, 14, 42-51.

Martí Carbonell, M.A., Sanz, C., Darbra, S., Garau, A., \& Balada, F. (1993). Is prolactin related with activity and emotional reactivity? Physiology and Behtavior, 53, 827-829.

Martín-Loeches, M., Gómez-Jarabo, G., \& Rubia, F.J. (1994). Human brain potentials of spatial location encoding into memory. Electroencephalography and Clinical Neurophysiology, 9), 363-373.

Martîn-Loeches, M., Valdés, B., Gómez-Jarabo, G., \& Rubja, F.J. (1998). Working memory within the ventral stream; Brain potentials of spatial location and motion direction encoding into memory. International Joumal of Neuroscience, 96, 87-105.

Martínez, M., Salvador, A., \& Simón, V.M. (1994). Behavioral changes over several successtul agonistic encounters between male mice: Effect of type of "standard opponent." Aggressive Behavior, 20, 441-451.

Martínez, M.P., \& Botella, C. (1996). Evaluación y tratamiento psicológico de la hipocondría: revisión y análisis critico. Psicología Conductual, 4, 29-62.
Martínez-Sanchís, S., Brain, P.F., Salvador, A., \& Simón, V.M. (1996). Long-term chronic treatment with Stanozolol lacks significant effects on aggression and activity in young and adult male laboratory mice. General Phamacology, 27, 293298.

Martínez-Sancbís, S., Salvador, A., Moya-Atbiol. L., GonzálezBono, E. \& Simón, V.M. (1998). Effects of chronic treatment of testosterone propionate on aggression and hormonal levels in intact male mice. Psychoneuroendocrinology, 23, 275-293.

Mataix, D., Junqué, C., Vallejo, J., Sánchez-Turet, M., Verger, K., \& Barrios, M. (1997). Hemispheric functional imbalance in a sub-clinical obsessive-compulsive sample assessed by the Continuous Performance Test, Identical Pairs Version. Psychiarny Research, 72, 115-126.

Mataró, M. \& Junqué, C. (1998), Quantitative MRI morphometric analysis of neurodevelopmental disorders. Medical Imaging International, 8, 6-8.

Mediavilla, C., Molina, F., \& Puerto, A. (1998). Bilateral lesions in the cerebellar interpositus-dentate region impair taste aversion learning in rats. Physiology and Behavior, 65, 25-33.

Morales, A., Cubero, I., \& Puerto, A. (1989). Mammillary polydipsia and diabetes insipidus: A study of the rhythmicity of water intake. Physiology and Behavior, 45, 911-915.

Morales, A., Torres, M.D., Megías, J.L., Cándido, A., \& Maldonado, A. (1992) Effect of Díazepam on successive negative contrast in one-way avoidance. Pharmacology, Biochemistry and Behavior, 43, 153-157.

Moro, M., Salvador, A., \& Simón, V.M. (1997). Effects of the repeated administration of d-amphetamine on agonistic behaviour of isolated male mice. Behavioural Pharmacology, 8. 309-318.

Mozaz, M.J., Martí, J.F., Carrera, E., \& De La Puente, E. (1990). Apraxia in a patient with lesion located in right sub-cortical area. Contex, 26, 651-655.

Mozaz, M.J., Peña, J., Barraquer, L.L., Martí, J, \& Goldstein, L. (1993). Use of body part as object in brain-damaged patients. The Clinical Neuropsychologist, 7, 39-47.

Nadal, R., Prat, G., Pallarés, M., Hernândez-Torres, M., \& Ferré, N. (1996). Effects of bromocriptine on self-administration of sweetened ethanol solutions in rats. Psychophamacology, 128, 45-53

Navarro, J.F., Miñarro, J., \& Simón, V.M. (1993). Antiaggressive and motor effects of haloperidol show different temporal patterns in the development of tolerance. Physiology and Behavior, 53, 1055-1059.

Navarro, M., Rubio, P., \& Rodríguez de Fonseca, F. (1995). Behavioural consequences of maternal exposure to natural cannabinoids in rats. Psychopharmacology, 122, $1-14$.

Nieto, A., Barroso, J., Olivares, T., Wollman, T., \& Hernández, M. (1996). Alteraciones neuropsicológicas en la esclerosis múltiple. Psicología Conductual, 4, 401-416.

Nieto, A., Hernández, S., González-Feria, L., \& Baitoso, J. (1990). Semantic capabilities of the left and right cerebral hemispheres in categorization tasks: Effects of verbal-pictorial presentation. Neuropsychologia, 28, 1175-1186. 
Nieto, A, Santacruz, R., Hernández, S., Camacho-Rosales, J., \& Barroso, J. (1999). Hemispheric asymmetry in lexical decisions: The effects of grammatical class and imageability. Brain and Language, 70, 421-436.

Ortega-Escobar, J., \& Muñoz-Cuevas, A. (1999). Anterior median eyes of Lycosa tarentula (Araneae, Lycosidae) detect polarized light: Behavioral experiments and electroretinographic analysis. Journal of Arachnology, 27, 663-671.

Pallarés, M.A., Nadal, R.A., Hernández-Torres, M., \& Ferré, N.A. (1997). ElOH self-administration on shuttle box avoidance learning and extinction in rats. Alcohol, 14, 503-509.

Parra A., Arenas, M.C., Monleón, S., Vinader-Caerols, C., \& Simón, V. (1999). Sex differences in the effects of neuroleptics on escape-avoidance behavior in mice: A review. Pharmacology. Biochemistry and Behavior, 64, 813-820.

Pásaro, E., Fernández, R., \& Méndez, J. (1993). Optical density profile analysis of trypsin-giemsa bands in human $X$ chromosomes. Annals of Human Genetics, 57, 117-121.

Peinado-Manzano, M.A. (1994) Amygdala, hippocampus and associative memory in rats. Behavioral Brain Research, 61 , 175-190.

Peinado-Manzano, M.A., \& Pozo-García, R. (1996). Retrograde amnesia in rats with dorsomedial thalamic damage. Behavioral Brain Research, 80, 177-184.

Perea, M.V., \& Ladera, V. (1997a). Interacción entre el déficit neuropsicológico en ejecución y la competencia en las actividades cotidianas en la demencia tipo Alzheimer. Revista de Neurología, 25, 513-518.

Perea, M.V., \& Ladera, V. (1997b). Rendimientos práxicos y grado de perfusión cerebral por SPECT en la demencia tipo Alzheimer. Psicothema, 11, 339-408.

Perea, M.V., Ladera, V., Blanco, A., \& Morales, F. (1999). Árbol de decisión diagnóstica para la correcta utilización de las técnicas de evaluación neuropsicológica en el traumatismo craneoencefálico. Revista de Neurologia, 28, 999-1006.

Persico, A.M., Schindler, C.W., Davis, S.C., Ambrosio, E., \& Uhl, G.R. (1998). Medial prefrontal cortical injections of c-fos antisense oligonucleotides transiently lower c-Fos protein and mimic amphetamine withdrawal behaviours. Neuroscience. 82 , 1115-1129.

Polo, M.D., Escera, C., Gual, C., \& Grau, C. (1999). Mismatch negativity and auditory sensory memory in chronic alcoholics. Alcoholism: Clinical and Experimental Research, 23, 1744-1750.

Portellano, J.A., Mateos, R., \& Martínez Arias, R. (2000). CUMANIN. Madrid: TEA.

Portellano, J.A., Mateos, R., Valle, M., \& Aizcun, J. (1997), Trastornos neuropsicológicos en níños de muy bajo peso al nacer en edad escolar. Acta Pediátrica, 55, 375-379.

Portellano, J.A., \& Robles, J.I. (1998). Lateralidad y funciones cognitivas. Estudio de su interacción. Clinica y Salud, 9, 549-562,

Pringatano, G.P., Bruna, O., Mataró, M., Muñoz. J.M., Fernández, S., \& Junqué, C. (1998). Initial disturbances for consciousness and resultant impaired awareness in Spanish patients with traumatic brain injury. Joumal of Head Trauma Rehabilitation, 5, 29-38.
Pujol, J., Junqué, C., Vendrell, P., Grau, J.M., \& Capdevila, A. (1992). Reduction of the substantia nigra width and motor decline in aging and Parkinson's disease. Archives of Neurology, 49. $1119-1122$.

Ramírez, J.M. (1993). Acceptability of aggression in four Spanish regions and a comparison with other European countries. Aggressive Behavior, 19, 185-197.

Ramírez, J.M. (1998). Aggression. In G. Greenberg \& M.M. Haraway (Eds.), Comparative psychology: A handbook (pp. 625-634). New York: Garland.

Ramos, J.M., Castillo, M.E., \& Puerto, A. (1989). Peripheral pathways mediating salivary secretion after nucleus parvocellularis activation in the rat. Brain Research Bulletin. $22,469-473$.

Ramos Platón, M.J., \& Espinar Sierra, J. (1992). Changes in psychopathological symptoms in sleep apnea patients after treatment with nasal continuous positive airway pressure. International Journal of Neuroscience, 62, 173-195.

Rodríguez-Arias, M., Miñarro, J., Aguilar, A., Pinazo, J., \& Simón, V.M. (1998). Effects of risperidone and SCH 23390 on isolation-induced aggression in male mice. European Neuropsychopharmacology, 8, 95-103.

Rodríguez de Fonseca, F., Carrera, M.R.A., Navarro, M., Koob, G. F., \& Weiss, F. (1997). Activation of corticotropin-releasing factor in the limbic system during cannabinoid withdrawal. Science, 276, 2050-2054.

Rodríguez de Fonseca, F., del Arco, I., Martín-Calderón, J.L., Gorriti, MA., \& Navarro, M. (1998). Role of the endogenous cannabinoid system in the regulation of motor activity. In F. Rodríguez de Fonseca \& M. Navarro (Eds.), Neurobiology of Disease [Special issue: Neurobiology of cannabinoid transmission], 5, 483-501.

Rodríguez Holguín, S., Corral, M., \& Cadaveira, F. (1998a). Visual and auditory event-related potentials in young children of alcoholics from high and low density families. Alcoholism: Clinical and Experimental Research, 22, 87-96.

Rodríguez Holguín, S., Corral, M., \& Cadaveira, F. (1998b). Eventrelated potentials elicited by infrequent non-target stimuli in young children of alcoholics. Family history and gender differences. Alcohol and Alcoholism, 33, 281-290.

Rodríguez Pérez, C., Vicente, F. de, \& Gómez-Jarabo, G. (1992). Effects of protein malnutrition and the administration of cortisol on the reflexologic developments. Behavioural and Neural Biology, 58, 165-170.

Rotzinger, S., Aragón, C.M.G., Rogan, F., Amir, S., \& Amit, Z. (1995). The nitric oxide synthase inhibitor Nw-nitro-L-arginine methylester attenuates brain catalase activity in vitro. Life Sciences, 56, 1321-1324.

Sabater Pi, J., Vea, J.J., \& Serrallonga, J. (1997). Did the first hominids build nests? Current Anthropology, 38, 914-916.

Salas, C., Herrero, L., Rodríguez, F., \& Torres, B. (1997). Tectal codification of eye movements in goldfish studied by electrical microstimulation. Neuroscience, 78, 271-288.

Salas, C., Rodríguez, F, Vargas, J.P., Durán, E., \& Torres, B. (1996). Spatial learning and memory deficits after telencephalic ablation 
in goldfish trained in place and turn maze procedures. Behavioral Neuroscience, 110, 1-16.

Sanchís, C., Suay, F., Valverde, M.J., \& Salvador, A. (1997). Nonmetabolic $\mathrm{VCO} 2$ responses to an incremental exercise test in judoists in the competitive season. Biology of Sport, 14, 29-36.

Sanchís-Segura, C., Miquel, M., Correa, M., \& Aragon, C.M.G. (1999). Cyanamide reduces brain catalase and ethanol-induced locomotor activity: Is there a functional link? Psychopharmacology, 144, 83-89.

Sandi, C., Borrell, J., \& Guaza, C. (1990). Administration of leuenkephalin impairs the acquisition of preference for ethanol. Psychopharmacology, 100, 350-354.

Sandi, C., Castanon, N., Vitjello, S., Neveu, P.J., \& Mormède, P. (1991). Different responsiveness of spleen iymphocytes from two lines of psychogenetically selected rats (Roman high- and low-avoidance). Joumal of Neuroimmunology, 31, 27-33.

Sandi, C., Loscertales, M., \& Guaza, C. (1997). Experience and time-dependent effects of corticosterone on spatial memory in rats. European Journal of Neuroscience, 9, 637-642.

Sandi, C., Patterson, T.A., \& Rose, S.P.R. (1993). Visual input and lateralization of brain function in learning in the chick. Neuroscience, 52, 393-401.

Sandi, C., \& Rose, S.P.R. (1994). Corticosteroid receptor antagonists are amnestic for passive avoidance learning in day-old chicks. European Journal of Neuroscience, 6, 1292-1297.

Santana, C., Moujir, F., Fajardo, N., Castaneira, A., Hernández, F.J, \& Abreu, P. (1994). Changes in tyrosine hydroxylase activity and melatonin synthesis in rat pineal glands throughout 72 hours of incubation. Neuroscience Letters, 173, 119-123.

Segovia, S., Cerro, M.C.R. del, Ortega, E., Pérez-Laso, C., Rodríguez-Zafra, M., Izquierdo, M.A.P., \& Guillamón, A. (1996). Role of GABA ${ }_{A}$ receptors in the organization of brain and behavioural sex differences. NeuroReport, 7, 2553-2557.

Segovia, S., \& Guillamon, A. (1993). Sexual dimorphism in the vomeronasal pathway and sex differences in reproductive behaviors. Brain Research Review, 18, 51-74.

Segovia, S., Guillamón, A., Cerro, M.C.R. del, Ortega, E., PérezLaso, C., Rodríguez-Zafra, M., \& Beyer, C. (1999). The development of brain sex differences: A multisignaling process. Behavioral Brain Research, 105, 69-80.

Segovia, S., Pérez-Laso, C., Rodríguez-Zafra, M., Calés, J.M., DelAbril, A., De-Blas, M.R., Collado, P., Valencia, A., \& Guillamón, A. (1991), Early postnatal Díazeparn exposure alters sex differences in the rat brain. Brain Research Bulletin, 26, 899-907.

Serra, J.M., Escera, C., Sánchez-Turet, M., Sánchez Sastre, J., \& Grau, C. (1996). The Hl-receptor antagonist chlorpheniramine decreases the ending phase of the mismatch negativity of the human auditory event-related potentials. Neuroscience Letters, $203,77-80$.

Serrano, J.M., Iglesias, J., \& Loeches, A. (1992). Visual discrimination and recognition of facial expressions of anger, fear, and surprise in 4- to 6-month-old infants. Developmental Psychobiology, 25, 411-425.

Suay, F., Salvador, A., González-Bono, E., Sanchís, C., Simón, V.M., \& Montoro, J.B. (1996). Testosterona y evaluación de la conducta agresiva en jóvenes judokas. Revista de Psicología del Deporte, 9-10, 79-91.

Tenas-Huerga, M., Coll-Andreu, M., Guillazo-Blanch, G., MartíNicolovius, M., \& Morgado-Bernal, I. (1998) Facilitatory effects of thalamic reticular nucleus lesions upon two-way active avoidance in rats. Experimental Brain Research, 118, 511-516.

Torras-García, M., Portell-Cortés, I., Costa-Miserachs, D., \& Morgado-Bernal, I. (1997) Long-term memory modulation by posttraining epinephrine in rats: Differential effects depending on the basic learning capacity. Behavioral Neuroscience, 111, 301-308.

Torres, C., Morales, A., Cándido, A., \& Maldonado, A. (1996). Successive negative contrast in one-way avoidance: Effect of thiopental sodium and chlorpromazine. European Journal of Pharmacology, 314, 269-275.

Vale-Martínez, A., Guillazo-Blanch, G., Aldavert-Vera, L., SeguraTorres, P., \& Marti-Nicolovius, M. (1999). Intracranial selfstimulation in the parafascicular nucleus of the rat. Brain Research Bulletin, 48, 401-406.

Valencia, A., Collado, P., Calés, J.M., Segovia, S., Pérez-Laso, C., Rodríguez-Zafra, M., Guillamón, A. (1992). Postnatal administration of dihydrotestosterone to the male rat abolishes sexual dimorphism in the accessory olfactory bulb: A volumetric study. Developmental Brain Research, 68, 132-135.

Valle-Inclán. F. (1996). The locus of interference in the Simón effect: An ERP study. Biological Psychology, 43,147-162.

Vea, J.J., \& Sabater Pi, J. (1998). Spontaneous pointing behaviour in the wild pygmy chipanzee ( $P$ an paniscus). Folia Primatologica, 69, 289-290.

Vendrell, P., Pujol, J., Junqué, C., \& Martí-Vilalta, J.L. (1995). Memory disfunctions in patients with vascular subcortical pathology. Facts and Research in Gerontology, (supplement), $75-82$.

Verger, K., Junqué, C., García, C., Pardo, N., Martí-Vilalta, J.L. (1996). Trastornos neuropsicológicos por lesión en el sistema frontoestriado izquierdo. Estudio longitudinal de un adolescente. Neurología, $11,44-47$.

Vicente F. de, Rodríguez Pérez M.C., \& Gomez-Jarabo, G. (1991). The effects of protein malnutrition and cortisol treatment on motor activity of rats. Behavioral Processes, 25, 1-14.

Zinner, D., \& Peláez, F. (1999). Verreaux's eagles (Aquila verreauxi) as potential predators of hamadryas baboons (Papio hamadryas) in Eritrea. American Journal of Primatology, 47, 61-66.

Zurrón, M., \& Díaz, F. (1995). Auditory and visual evoked potentials in subjects with organic and cultural-familial mental retardation. American Journal on Mental Retardation, 100, 3, $271+282$. 